\title{
Effects of Two Different Dose Levels of Irradiation on Thioredoxin Reductase in the Kidney of Guinea Pigs
}

\author{
${ }^{1}$ Nedret Kilıc, ${ }^{2}$ Yildiz Guney, ${ }^{2}$ Ayse Hıcsonmez, ${ }^{1}$ Melike Erol, ${ }^{1}$ Ferhan Kömürcü \\ ${ }^{3}$ Ayşen Dizman, ${ }^{1}$ Ummuhani Ozel Turkcu and ${ }^{2}$ Meltem Nalca Andrieu \\ ${ }^{1}$ Gazi University School of Medicine Department of Biochemistry, Ankara, Turkey \\ ${ }^{2}$ Ankara University School of Medicine Department of Radiation Oncology, Ankara, Turkey \\ ${ }^{3}$ Department of Radiation Oncology, Ankara Oncology Hospital, Ankara, Turkey
}

\begin{abstract}
It is aimed to examine the state of the oxidant-antioxidant system in the liver of guinea pig caused by ionizing radiation at two different dose levels in the early period. The research was carried out on guinea pigs irradiated with the doses of 8 Gy (group 2) or 15 Gy (group 3) (single dose/whole body) in comparison with control group (group 1). The levels of thioredoxin reductase (TR) in the kidney was measured. The results obtained by non-irradiated and irradiated (8 Gy and 15 Gy) kidneys on guinea pigs indicated that; in 8-15 Gy irradiated animal kidneys TR activity elevated significantly $(p<0.001)$ when compared to the controls, but there was no difference between 8 Gy and 15 Gy irradiated animal groups. The data have shown that gamma-irradiation results in significant increase in TR activity at two different dose levels.
\end{abstract}

Key words: Irradiation, thioredoxin reductase, kidney, guinea pigs

\section{INTRODUCTION}

Radiation is known to produce various reactive oxygens species (ROS) in biological systems such as superoxide, hydrogen peroxide and hydroxyl radicals and various types of tissue damage due to free radical reactions ${ }^{[1]}$. The generation of ROS plays an important role in the pathogenesis of irradiation-induced tissue injury ${ }^{[2]}$. The range of antioxidant defenses available within the cell and in the extracellular fluid should be adequate to protect against oxidative damage ${ }^{[1]}$. DNA, lipids and proteins are attacked by free radicals induced by ionizing radiation ${ }^{[3-5]}$. Oxidative stress clearly plays a crucial role in the development and pathogenesis of chronic renal failure ${ }^{[6]}$.

Many reasons involved in the development and progression of radiation nephropathy remain ill defined $^{[7]}$. There is little information about the kidney damage after irradiation exposure. The biological effects of ionizing radiation result from energy deposition in irradiated cells and subsequent acute generation of short-lived $\operatorname{ROS}^{[8]}$. Free radicals are very reactive short-lived species and their direct measurement in vivo is difficult. Thus, ongoing oxidative damage has generally been analyzed indirectly by measurement of secondary products of oxidation $^{[9]}$. This oxidative stress, associated with ROS is believed to be involved in the pathophysiological role in many diseases such as heart disease (atherosclerosis), cataract, cancer (neoplastic diseases) ${ }^{[10]}$.
The thioredoxin system (thioredoxin, thioredoxin reductase (TR) and NADPH) is a ubiquitous thiol oxidoreductase system that regulates cellular reduction/oxidation (redox) status ${ }^{[11]}$ that plays an important role in cell function by limiting oxidative stress $^{[12,13]}$.

Hence, the present study has been undertaken to study an antioxidant enzyme TR in kidney tissue of guinea pigs which have been irradiated at two different dose levels.

\section{MATERIALS AND METHODS}

Animals and irradiation: Guinea pigs weighting approximately $350 \mathrm{~g}$, were used in this study. The Guniea pigs were divided into three groups each consisting of 10 animals. Group 1: Control; Group 2: Irradiated with a dose of 8 Gy (single dose, wholebody); Group 3: Irradiated with a dose of 15 Gy (single dose, whole-body). Irradiation was carried out using a ${ }^{60} \mathrm{Co}$ source. All animal procedures were carried out according to the rules of Gazi University Animal Care and Ethics Committee.

The animals in Group 2 were exposed to a dose of 8 Gy irradiation by $\gamma$-rays of ${ }^{60} \mathrm{Co}$, with a source-axisdistance (SAD) of $80 \mathrm{~cm}$ whole-body following ketamine hydrochloride anesteshia. The guinea pigs in Group 3 were subjected to a dose of 15 Gy whole-body irradiation following anesthesia. Twenty four $\mathrm{h}$ after irradiation, all animals were euthanized using ketamine

Corresponding Author: Yildiz GUNEY :Ankara University School of Medicine, Department of Radiation Oncology, Cebeci Hospital, Dikimevi, Ankara, 06100 Turkey, Tel: +90 312 5956096, Fax: +90 3123621495 
hydrochloride $\left(\right.$ ketalar $^{\circledR}$, Eczacibasi, Turkey). The tissues were briefly washed in ice-cold $0.9 \%$ saline $(\mathrm{w} / \mathrm{v})$ and frozen in liquid nitrogen. The tissues were stored at $-70{ }^{\circ} \mathrm{C}$ until the subsequent protein and enzyme assays.

Purification of tissue thioredoxin reductase ${ }^{[14]}$ : Reduced glutathione (GSH) and other low molecular thiols interfere in the assay systems. They were removed initially by the common batch steps. Each tissue was homogenized at a ratio of $1 / 10$ in $50 \mathrm{mM}$ Tris-HCl, $\mathrm{pH}$ 7.5, $1 \mathrm{mM}$ EDTA (TE buffer) and centrifuged at $13,000 \mathrm{~g}$ for $30 \mathrm{~min}$ at $+4^{0} \mathrm{C}$. $\mathrm{pH}$ of the supernatants were adjusted to 5.0 by dropwise addition of ice-cold acetic acid, $1.0 \mathrm{M}$, followed by centrifugation at $13,000 \mathrm{~g}$ for $20 \mathrm{~min}$ at $+4^{0} \mathrm{C}$ to remove the precipitates formed. Each supernatant was adjusted to $\mathrm{pH} 7.5$ with $1.0 \mathrm{M} \mathrm{NH}_{4} \mathrm{OH}$. The protein measurements were carried out according to Lowry ${ }^{[15]}$ and all the supernatants were heated to $60^{\circ}$ in a shaking water bath. They were than rapidly cooled to $4^{0}$ in an ice bath, followed by centrifugation at $13,000 \mathrm{~g}$ for 20 min at $+4^{0} \mathrm{C}$ to remove the precipitates. Ammonium sulfate was added gently to $85 \%$ saturation to each supernatant and the precipitates were collected by centrifugation at $13,000 \mathrm{~g}$ for $20 \mathrm{~min}$ at $+4^{0} \mathrm{C}$. Each precipitate was dissolved in a small volume of TE buffer and filtered through an ultrafiltration membrane (amicon Millipore, Regenerated cellulose, Fitler code: YM3, Dia: $14 \mathrm{~mm}$, NMWL: 3, 000) by centrifugation at $2,000 \mathrm{~g}$ for $5 \mathrm{~min}$ at $+4^{0} \mathrm{C}$. Upper volume was used for the subsequent enzyme activity and protein assays.

Measurement of thioredoxin reductase activity ${ }^{[14]}$ : TR reduces 5,5'-dithiobis (2-nitrobenzoic acid) (DTNB) by NADPH and produces TNB (5'thionitrobenzoic acid) which is yellow and has an absorbance maximum at $412 \mathrm{~nm}$. A reaction mixture was prepared by the addition of $50 \mu 1$ of NADPH (40 $\mathrm{mg} / \mathrm{ml}$ in water), $0.5 \mathrm{ml}$ of EDTA $(0.2 \mathrm{M}), 1.0 \mathrm{ml}$ of potassium phosphate buffer, $1.0 \mathrm{M}, \mathrm{pH} 7.0,0.8 \mathrm{ml}$ of DTNB $(25 \mathrm{mg} / \mathrm{ml}$ in $99.5 \%$ ethanol, $100 \mu \mathrm{l}$ of BSA (bovine serum albumin; $20 \mathrm{mg} / \mathrm{ml}$ ) and water to a final volume of $10 \mathrm{ml} .500 \mu \mathrm{l}$ of the reaction mixture was added to the spectrophotometry cuvettes. $100 \mu \mathrm{l}$ of each protein sample was added to each sample cuvette whereas $100 \mu \mathrm{l}$ of buffer was added to the reference cuvette. The reaction was followed at $412 \mathrm{~nm}$ for $3 \mathrm{~min}$.

Calculation of activity: 1 IU TR activity produces 1 $\mu$ moles of TNB in $1 \mathrm{~min}$ at constant temperature $\left(25^{0}\right.$ C) and $\mathrm{pH}$. Since TNB has an absorbance maximum at $412 \mathrm{~nm}$ with an extinction coefficient of $13,600 \mathrm{M}^{-1} \mathrm{~cm}^{-}$ ${ }^{1}, \Delta \mathrm{A}=$ am.$\Delta \mathrm{c} .1$ equation was used to calculate the $\mu$ moles of TNB produced $/ \mathrm{min}$. The results were expressed as $\mathrm{U} / \mathrm{mg}$ tissue protein. Protein measurements were carried out according to BradfordS method $^{[16]}$.
Statistics: Kruskal Wallis variance analysis and MannWhitney U test were used by the SPSS 10.0 for Windows. Values of $\mathrm{p}<0.05$ were regarded as significant. Results were presented as mean \pm SEM.

\section{RESULTS AND DISCUSSION}

The results obtained by non-irradiated and irradiated ( 8 Gy and 15 Gy) kidneys on guinea pigs presented in Fig. 1 indicated that; in 8-15 Gy irradiated animal kidneys TR activity elevated significantly $(p<0.001)$ when compared to the controls, but there was no difference between 8 Gy and 15 Gy irradiated animal groups.

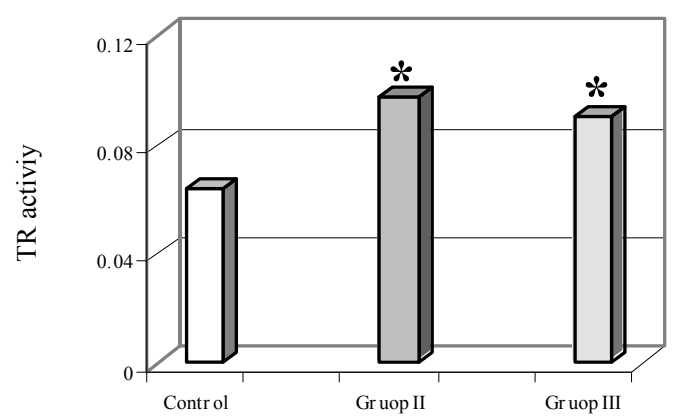

Fig. 1: Thioredoxin reductase (TR) activiy in guinea pig kidney after total body (TB) irradiation ${ }^{*} \mathrm{p}<0.005$, compared to control group

The use of ionizing radiation to kill tumor cells is a common treatment of cancer ${ }^{[17]}$. Radiation-produced free radicals are believed to be crucial for the radiationinduced tissue injury ${ }^{[18]}$. However, organisms have protective systems against free radical reactions, such as endogenous antioxidants and antioxidative enzymes $^{[19]}$.

The results of recent studies demonstrated that total body irradiation in rats causes tissue damage in kidneys, liver, lungs, colon and ileum ${ }^{[20]}$. TR and TRX may be potential molecular targets for anticancer and sensitizing agents ${ }^{[21]}$.

The thioredoxin reductases (TRs) are enzymes belonging to the flavoprotein family of pyridine nucleotide-disulphide oxidoreductases that includes also glutathione reductase ${ }^{[22]}$.

In this study, significant elevation of TR was seen after irradiation at two different dose levels. These results suggest that TR provide protection against ROSmediated nephrotoxicity.

As a result, in the early period, high doses of ionizing radiation (8 Gy and $15 \mathrm{~Gy}$ ) influences the oxidant-antioxidant system in kidneys of guinea pigs. Since the modulation of balance of oxidant and antioxidant system is critically important in the pathogenesis of tissue damage such as kidneys and thioredoxin exerts important protective roles against ROS, it seems likely that thioredoxin system may be a promising target for clinical therapy. 


\section{REFERENCES}

1. Adler, V., Z. Yin and K.D. Tew and Z. Ronai, 1999. Role of redox potential and reactive oxygen species in stress signaling. Oncogene 18: 104-111.

2. Agrawal, A., D. Chandra and R.K. Kale, 2001. Radiation-induced oxidative stress: 2 studies in liver as distant organ of tumor bearing mice. Mol. Biochem., 224: 9-17.

3. Reiter, R.J., J.R. Calvo, M. Karbownik, W. Qi and D.X. Tan, 2000. Melatonin and its relation to the immune system and inflamation. Ann. NY Acad. Sci., 917: 376-386.

4. Reiter, R.J., D.X. Tan, C. Osuna and E. Gitto, 2000. Actions of melatonin in the reduction of oxidative stress: A review. J. Biomed. Sci., 7: 444458.

5. Edwards, J.C., D. Chapman, W.A. Cramp and M.B. Yatvin, 1984. The effects of ionizing radiation on biomembrane structure and function. Prog. Biophys. Mol. Biol., 43: 71-93.

6. Annuk, M., I. Soveri, M. Zilmer, L. Lind, J. Hulthe and B. Fellstrom, 2005. Endothelial function, CRP and oxidative stress in chronic kidney disease. J. Nephrol., 18: 721-6.

7. Robbins, M.E.C. and S.M. Bonsib, 1995. Radiation nephropathy: A review. Scanning Microsc., 9: 535-560.

8. Riley, P.A., 1994. Free radicals in biology: Oxidative stress and the effects of ionizing radiation. Intl. J. Rad. Biol., 65: 27-33.

9. Frank, J., H.K. Biesalski, S. Dominici and A. Pompella, 2000. The visualization of oxidant stress in tissues and isolated cells. Histol. Pathol., 15: 173-184.

10. Halliwell, B. and J.M.C. Gutteridge, 1984. Oxygen toxicity, oxygen radicals, transition metals and disease. Biochem. J., 219: 1-14.

11. Mustacich, D. and G. Powis, 2000. Thioredoxin reductase. Biochem. J., 346: 1-8.

12. Oberley, T.D., E. Verwiebe, W. Zhong, S.W. Kang and S.G. Rhee, 2001. Localization of the thioredoxin system in normal rat kidney. Free Radic. Biol. Med., 30: 412-24.
13. Yamawaki, H. and B.C. Berk, 2005. Thioredoxin: a multifunctional antioxidant enzyme in kidney, heart and vessels. Curr. Opin. Nephrol. Hypertens., 14: 149-53.

14. Holmgren, A and M. Björnstedt, 1995. Thioredoxin and thioredoxin reductase. Methods Enzymol., 252: 199-208.

15. Lowry, O.H., N.J. Rosenbrough and A.L. Farr, 1951. Protein measurement with the folin reagent. J. Biol. Chem., 193: 265-275.

16. Bradford, M.M., 1976. A rapid and sensitive method for the quantitation of microgram quantities of protein-dye binding. Anal. Biochem., 258: 248-254.

17. Miura, Y., A. Kaunorı and S. Urano, 1997. In vivo electron parmagnetic resonanse studies on oxidative stress caused by $\mathrm{x}$-irradiation whole mice. Free Radic. Biol. Med., 23: 533-540.

18. Savarese, D.M., G. Savy, L. Vahdat, P.E. Wischmeyer and B. Corey, 2003. Prevention of chemotherapy and radiation toxicity with glutamine. Cancer Treat Rev., 29: 501-513.

19. Winterbourn, C.C., 1993. Superoxide as an intracellular radical sink. Free Radic. Biol. Med., 14: 85-90.

20. Sener, G., N. Jahovic,O. Tosun, B.M. Atasoy and B.C. Yegen, 2003. Melatonin ameliorates ionizing radiation-induced oxidative organ damage in rats. Life Sci., 74: 563-72.

21. Berggren, M., A. Gallegos, J.R. Gasdaska, P.Y. Gasdaska, J. Warneke and G. Powis, 1996. Thioredoxin and thioredoxin reductase gene expression in human tumors and cell lines and the effects of serum stimulation and hypoxia. Anticancer Res., 16: 3459-66.

22. Williams, Jr.C.H., 1995. Chemistry and Biochemistry of Flavoenzymes. (Muller, F., Ed.), CRC Press, Boca Raton), pp: 121-211. 